\title{
Photomineralization and photomethanification of dissolved organic matter in Saguenay River surface water
}

\author{
Y. Zhang ${ }^{1,2}$ and H. Xie ${ }^{2}$ \\ ${ }^{1}$ Key Laboratory of Coastal Environmental Processes and Ecological Remediation, Yantai Institute of Coastal Zone Research, \\ Chinese Academy of Sciences, Yantai, Shandong Province 264003, People's Republic of China \\ ${ }^{2}$ Institut des sciences de la mer de Rimouski, Université du Québec à Rimouski, Rimouski, Québec G5L 3A1, Canada \\ Correspondence to: H. Xie (huixiang_xie@uqar.ca)
}

Received: 28 July 2015 - Published in Biogeosciences Discuss.: 31 August 2015

Revised: 10 November 2015 - Accepted: 15 November 2015 - Published: 30 November 2015

\begin{abstract}
Rates and apparent quantum yields of photomineralization $(\mathrm{AQY}$ DOC $)$ and photomethanification $\left(\mathrm{AQY}_{\mathrm{CH}_{4}}\right)$ of chromophoric dissolved organic matter (CDOM) in Saguenay River surface water were determined at three widely differing dissolved oxygen concentrations $\left(\left[\mathrm{O}_{2}\right]\right.$ ) (suboxic, air saturation, and oxygenated) using simulated-solar radiation. Photomineralization increased linearly with CDOM absorbance photobleaching for all three $\mathrm{O}_{2}$ treatments. Whereas the rate of photochemical dissolved organic carbon (DOC) loss increased with increasing $\left[\mathrm{O}_{2}\right]$, the ratio of fractional DOC loss to fractional absorbance loss showed an inverse trend. CDOM photodegradation led to a higher degree of mineralization under suboxic conditions than under oxic conditions. AQY ${ }_{\text {DOC }}$ determined under oxygenated, suboxic, and air-saturated conditions increased, decreased, and remained largely constant with photobleaching, respectively; $\mathrm{AQY}_{\mathrm{DOC}}$ obtained under air saturation with short-term irradiations could thus be applied to longer exposures. AQY decreased successively from ultraviolet $B$ (UVB) to ultraviolet A (UVA) to visible (VIS), which, alongside the solar irradiance spectrum, points to VIS and UVA being the primary drivers for photomineralization in the water column. The photomineralization rate in the Saguenay River was estimated to be $2.31 \times 10^{8} \mathrm{~mol} \mathrm{Cyr}^{-1}$, accounting for only $1 \%$ of the annual DOC input into this system.

Photoproduction of $\mathrm{CH}_{4}$ occurred under both suboxic and oxic conditions and increased with decreasing $\left[\mathrm{O}_{2}\right]$, with the rate under suboxic conditions $\sim 7-8$ times that under oxic conditions. Photoproduction of $\mathrm{CH}_{4}$ under oxic conditions increased linearly with photomineralization and photobleaching. Under air saturation, $0.00057 \%$ of the photo-
\end{abstract}

chemical DOC loss was diverted to $\mathrm{CH}_{4}$, giving a photochemical $\mathrm{CH}_{4}$ production rate of $4.36 \times 10^{-6} \mathrm{~mol} \mathrm{~m}^{-2} \mathrm{yr}^{-1}$ in the Saguenay River and, by extrapolation, of (1.9$8.1) \times 10^{8} \mathrm{~mol} \mathrm{yr}^{-1}$ in the global ocean. $\mathrm{AQY}_{\mathrm{CH}_{4}}$ changed little with photobleaching under air saturation but increased exponentially under suboxic conditions. Spectrally, $\mathrm{AQY}_{\mathrm{CH}_{4}}$ decreased sequentially from UVB to UVA to VIS, with UVB being more efficient under suboxic conditions than under oxic conditions. On a depth-integrated basis, VIS prevailed over UVB in controlling $\mathrm{CH}_{4}$ photoproduction under air saturation while the opposite held true under $\mathrm{O}_{2}$-deficiency. An addition of micromolar levels of dissolved dimethyl sulfide (DMS) substantially increased $\mathrm{CH}_{4}$ photoproduction, particularly under $\mathrm{O}_{2}$-deficiency; DMS at nanomolar ambient concentrations in surface oceans is, however, unlikely a significant $\mathrm{CH}_{4}$ precursor. Results from this study suggest that CDOM-based $\mathrm{CH}_{4}$ photoproduction only marginally contributes to the $\mathrm{CH}_{4}$ supersaturation in modern surface oceans and to both the modern and Archean atmospheric $\mathrm{CH}_{4}$ budgets, but that the photochemical term can be comparable to microbial $\mathrm{CH}_{4}$ oxidation in modern oxic oceans. Our results also suggest that anoxic microniches in particulate organic matter and phytoplankton cells containing elevated concentrations of precursors of the methyl radical such as DMS may provide potential hotspots for $\mathrm{CH}_{4}$ photoproduction. 


\section{Introduction}

Solar radiation in the ultraviolet (UV) and visible (VIS) regimes can break down chromophoric dissolved organic matter (CDOM), leading to the loss of absorbance (i.e. photobleaching) (Del Vecchio and Blough, 2002) and dissolved organic carbon (DOC, i.e. photomineralization) (Obernosterer and Benner, 2004) and the production of $\mathrm{CO}_{2}$ (Miller and Zepp, 1995), biolabile carbon (Kieber et al., 1989; Miller et al., 2002), and various biologically and atmospherically active trace compounds (Moran and Zepp, 1997; Liss et al., 2014). Photomineralization alone or combined with photochemically stimulated biomineralization has been suggested as a significant sink of DOC in many rivers and lakes (e.g. Bertilsson and Tranvik, 2000; Vähätalo and Wetzel, 2004; Cory et al., 2014) and a major sink of terrigenous DOC in coastal and shelf waters (Miller and Zepp, 1995; Aarnos et al., 2012; Fichot and Benner, 2014). Many trace gases produced from CDOM-involved photoprocesses are supersaturated in natural waters (e.g. carbonyl sulfide, iodomethane, carbon monoxide), thereby contributing to their budgets in the atmosphere (Liss et al., 2014). CDOM photochemistry therefore plays an important role in biogeochemical cycling of DOC and trace gases in natural waters (Mopper and Kieber, 2002; Zafiriou, 2002).

Methane $\left(\mathrm{CH}_{4}\right)$, the second most important greenhouse gas, is one of the trace gaseous compounds known to emit from aquatic systems to the atmosphere (Cicerone and Oremland, 1988; IPCC, 2013). Although $\mathrm{CH}_{4}$ in natural waters has long been thought to be produced exclusively under anaerobic conditions (Reeburgh, 2007), recent studies have revealed that aerobic microbial metabolism can also generate $\mathrm{CH}_{4}$ through decomposition of methylated precursors, such as methylphosphonates (Karl et al., 2008; Metcalf et al., 2012). More recently, a number of studies observed correlations between $\mathrm{CH}_{4}$ concentration and concentrations of dimethylsulfoniopropionate (DMSP) and/or dimethylsulfoxide (DMSO) in the Arctic and Pacific oceans (Damm et al., 2008, 2015; Weller et al., 2013; Zindler et al., 2013). Carbon isotope tracer experiments also confirmed DMSP and its degradation product, dimethylsulfide (DMS), to be plausible substrates of methylotrophic microbes leading to $\mathrm{CH}_{4}$ production in surface seawater (Damm et al., 2010; Florez-Leiva et al., 2013). In addition to biomethanation, abiotic processes have also been suggested as potential $\mathrm{CH}_{4}$ production pathways in oxygenated natural waters. Tilbrook and Karl (1995) observed formation of $\mathrm{CH}_{4}$ from sediment trap-collected sinking particles after exposure to solar radiation and suspected a photochemical source. Bange and Uher (2005) assessed the possibility of $\mathrm{CH}_{4}$ photoproduction (i.e. photomethanification) from CDOM in a number of river and estuarine systems and concluded that this pathway is significant only under anoxia in the presence of an added methyl radical precursor. They only tested acetone but suggested that other watersoluble methyl radical precursors such as acetonitrile, me- thionine, and dimethyl sulfide (DMSO), could be good candidates as well.

The purpose of this study is to explore the role of photochemistry in the cycling of DOC and $\mathrm{CH}_{4}$ in the highly colored surface water of the Saguenay River on the north shore of the St. Lawrence estuary (Canada). We determined the apparent quantum yields (AQYs) of photomineralization and photomethanification of CDOM and examined the effects of dissolved oxygen $\left(\mathrm{O}_{2}\right)$ and the dose and spectral composition of incident light on these two photoprocesses. Given the recent finding of the involvement of DMS in microbial $\mathrm{CH}_{4}$ production (Florez-Leiva et al., 2013), we also investigated this compound as a potential precursor of $\mathrm{CH}_{4}$ photochemically produced.

\section{Experimental section}

\subsection{Study site and sample collection}

The Saguenay River (Fig. 1), extending $165 \mathrm{~km}$ long from Lac Saint-Jean to Tadoussac and having a mean discharge of $1194 \mathrm{~m}^{3} \mathrm{~s}^{-1}$ (Bélanger, 2003), is the principal tributary of the St. Lawrence estuary. Seasonal variations in both discharge rate and water quality tend to be equalized due to regulation by hydropower dams in the upper reach of the river (Schafer et al., 1990; Roy et al., 2000). The Saguenay River intersects the St. Lawrence estuary near Tadoussac, where tides can propagate upriver to $\sim 15 \mathrm{~km}$ upstream of Chicoutimi. About $15 \mathrm{~km}$ downstream of Chicoutimi lies the Saguenay Fjord, which is characterized by a strong vertical stratification with a thin surface mixed layer of 5-20 $\mathrm{m}$ in summer (Drainville, 1968) and a thinner layer in winter (Bourgault et al., 2012). Terrigenous humic substance is the dominant component (over $50 \%$ in terms of DOC) of dissolved organic matter in the surface water of the fjord (Tremblay and Gagné, 2009) and CDOM behaves conservatively in the entire water column (Xie et al., 2012).

Surface water was taken at Chicoutimi $\left(48.4^{\circ} \mathrm{N}, 71.1^{\circ} \mathrm{W}\right)$ at ebb tide on 20 November 2013 using a clean high-density polyethylene bucket, transferred into $20 \mathrm{~L}$ acid-washed, collapsible polyethylene bags (Cole-Parmer), and immediately brought back to the laboratory in Rimouski. The water was gravity-filtered through Whatman ${ }^{\circledR}$ Polycap 75 AS filtration capsules sequentially containing $0.2 \mu \mathrm{m}$ glass microfiber and Nylon membrane filters. The capsules were extensively flushed with Nanopure water and then sample water before they were used to avoid contamination. This procedure removed more than $99 \%$ of bacteria as confirmed by flow cytometry with an Epics Altra flow cytometer (Beckman Coulter) following the procedure reported by Xie et al. (2009). Salinity was measured to be 0.1 using an YSI model 30 handheld salinity, conductivity and temperature system. All samples were kept at $4{ }^{\circ} \mathrm{C}$ in the dark until further processing. 


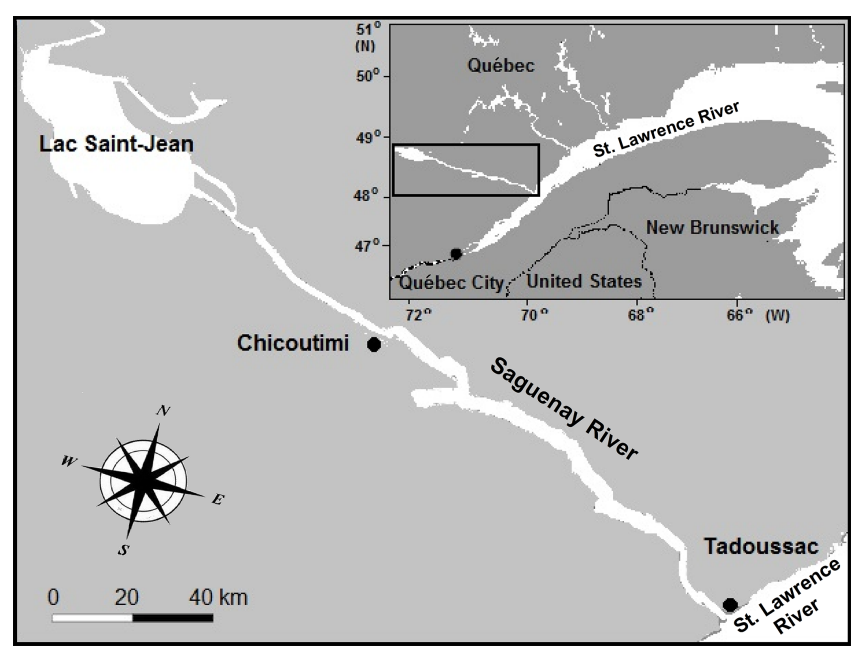

Figure 1. Map of the Saguenay River. Water samples were taken at the riverside of Chicoutimi.

\subsection{Irradiation}

Immediately before irradiation, water samples were refiltered through $0.2 \mu \mathrm{m}$ nylon filters (Millipore) to minimize bacterial contamination. To assess the effect of dissolved $\mathrm{O}_{2}$ on the photoprocesses of interest, samples were bubbled with medical-grade air, pure $\mathrm{O}_{2}$, and pure $\mathrm{N}_{2}$ (Air Liquid) for at least $1.5 \mathrm{~h}$ to obtain three widely different levels of $\mathrm{O}_{2}$. Dissolved $\mathrm{O}_{2}$ concentrations $\left(\left[\mathrm{O}_{2}\right] \mathrm{s}\right)$ were measured to be $271.2 \mu \mathrm{mol} \mathrm{L}^{-1}, 1023.0$ and $53.1 \mu \mathrm{mol} \mathrm{L}^{-1}$ in the air-, $\mathrm{O}_{2-}$, and $\mathrm{N}_{2}$-purged water, respectively. The $\left[\mathrm{O}_{2}\right]$ in the $\mathrm{N}_{2}-$ purged water was slightly higher than expected from equilibrium with pure $\mathrm{N}_{2}$ while vice versa for the $\mathrm{O}_{2}$-purged water due mainly to exchange with the atmosphere during sample transfer. Herein the air-, $\mathrm{O}_{2-}$, and $\mathrm{N}_{2}$-bubbling are referred to as air, $\mathrm{O}_{2}$, and $\mathrm{N}_{2}$ treatment, respectively. After bubbling, water was transferred into cylindrical quartz cells (length: $25.0 \mathrm{~cm}$; i.d.: $2.2 \mathrm{~cm}$ ). The cells were sealed without headspace with ground glass stoppers following sufficient overflowing. The value of $\mathrm{pH}$ remained constant (7.22) under air-purging but increased significantly under $\mathrm{O}_{2}$ - and $\mathrm{N}_{2}$-purging. In the latter case, the $\mathrm{pH}$ was adjusted to the initial value with $0.1 \mathrm{~N} \mathrm{HCl}$ (ACS grade, $\mathrm{BDH}$ ) to minimize potential effects of $\mathrm{pH}$ variation on CDOM photochemistry (Anesio and Granéli, 2003; Molot et al., 2005; Hong et al., 2014).

Irradiations were performed using a Suntest XLS+ solar simulator equipped with a $1500 \mathrm{~W}$ xenon lamp. The samplefilled quartz cells were horizontally immersed $(\sim 2 \mathrm{~mm}$ below water surface) in a temperature-controlled water bath $\left(20 \pm 1^{\circ} \mathrm{C}\right)$ located immediately beneath the exposure chamber of the solar simulator. Samples were irradiated under full spectrum in time series up to $181.8 \mathrm{~h}$, duplicate samples being sacrificed at each time point for analysis. Photon fluxes reaching the irradiation surface were determined

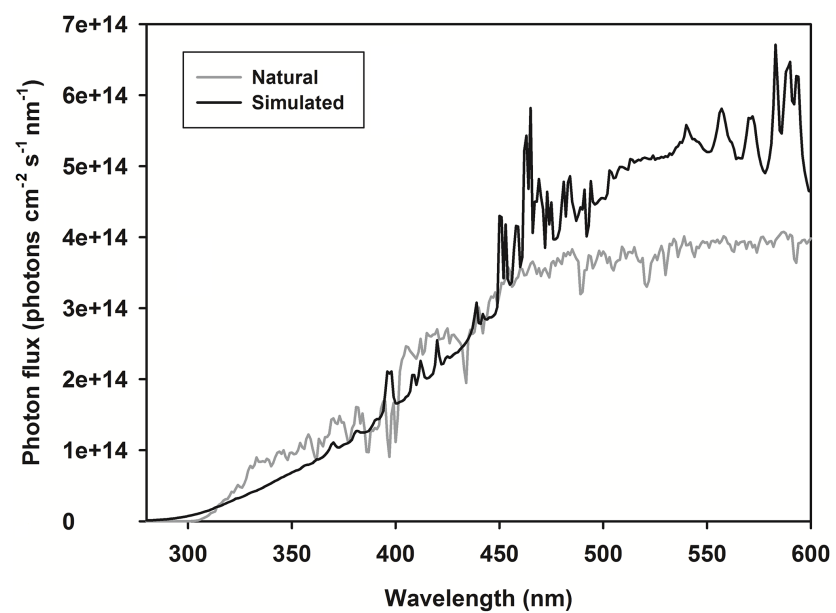

Figure 2. UV and visible spectra of the solar-simulated radiation and noontime clear-sky solar radiation recorded at Rimouski $\left(48.453^{\circ} \mathrm{N}, 68.511^{\circ} \mathrm{W}\right)$, Québec, on 24 May 2014.

at intervals of $1 \mathrm{~nm}$ using an OL-754 spectroradiometer fitted with a 2 inch OL IS-270 integrating sphere calibrated with an OL 752-10E irradiance standard (Optronics Laboratories). The solar simulator's photon fluxes in the UVB (280$320 \mathrm{~nm})$, UVA $(320-400 \mathrm{~nm})$, and VIS (400-600 nm) were, respectively, 1.54, 0.85, and 1.25 times those of the noontime clear-sky sunlight measured in May at Rimouski $\left(45.5^{\circ} \mathrm{N}\right)$, Canada (Fig. 2). One hundred and eighty-one point eight hours of solar-simulated irradiation thus corresponded to 19.7-d UVB, 35.7-d UVA and 24.2-d VIS irradiations with clear-sky sunlight at the latitude of $45.5^{\circ} \mathrm{N}$, assuming 1-d clear-sky irradiation to be equivalent to $6 \mathrm{~h}$ noontime irradiation (Miller and Zepp, 1995).

Additional irradiations of $\mathrm{N}_{2}$ - and air-purged samples (in triplicate) were conducted using Mylar-D films (50\% transmittance cutoff at $324 \mathrm{~nm})$ and UF-4 Plexiglas sheets (50\% transmittance cutoff at $408 \mathrm{~nm}$ ) as light filters to evaluate the relative importance of UVB (full spectrum minus Mylar-D), UVA (Mylar-D minus UF-4), and VIS (UF-4) radiation in the photoprocesses examined. Irradiations underwent in a startend mode and lasted from 48 to $75 \mathrm{~h}$, being shorter for $\mathrm{N}_{2}$ purged samples than for air-purged samples.

To evaluate if DMS can produce $\mathrm{CH}_{4}$ through CDOMmediated photochemistry, the re-filtered water was amended with $20.0 \mu \mathrm{mol} \mathrm{L}^{-1}$ DMS ( $\geq 99.0 \%$ purity, Sigma-Aldrich) and irradiated under full spectrum in time series up to $166.3 \mathrm{~h}$ (in duplicate). In addition, a start-end type of irradiation $(44.3 \mathrm{~h})$ was carried out with samples forming a DMS concentration series of $10.0,20.0,50.0$, and $100.0 \mu \mathrm{mol} \mathrm{L}^{-1}$. The DMS tests used air- and $\mathrm{N}_{2}$-purged samples only. All irradiated samples were accompanied with parallel dark controls which showed no significant changes in the variables measured in this study. 


\subsection{Analysis}

$\mathrm{CH}_{4}$ was measured using a static headspace method similar to that reported by Xie et al. (2002) for dissolved carbon monoxide measurement. Briefly, water samples were transferred to a $50 \mathrm{~mL}$ glass syringe, into which $5 \mathrm{~mL} \mathrm{CH}_{4}$-free $\mathrm{N}_{2}$ was introduced to obtain a 1:6 gas: water ratio. The syringe was vigorously shaken for $4 \mathrm{~min}$ and the equilibrated headspace gas was injected into a Peak Performer 1 FID gas chromatograph ( $2 \mathrm{~mL}$ sample loop; Peak Laboratories, USA) for $\mathrm{CH}_{4}$ quantification. The analyzer was standardized by frequent injections of a gaseous $\mathrm{CH}_{4}$ standard of 4.8 parts per million by volume (ppmv) (balance: $\mathrm{N}_{2}$; Air Liquide) traceable to the National Institute of Standards and Technology (NIST). Such a single-point calibration protocol was adopted since pre-study tests confirmed that the analyzer consistently responded linearly up to $10.5 \mathrm{ppmv}$. In keeping with the samples' $100 \%$ relative humidity, the dry $\mathrm{CH}_{4}$ standard was saturated with water vapor before injection. To estimate the analytical blank, a water sample was repeatedly extracted with pure $\mathrm{N}_{2}$ until its $\mathrm{CH}_{4}$ signal diminished to a stable level. Nine subsequent analyses of the extracted sample arrived at a mean blank of $0.034 \mathrm{nmol} \mathrm{L}^{-1}$ with a standard deviation of $0.015 \mathrm{nmol} \mathrm{L}^{-1}$. The lower detection limit, defined as three times the blank, was thus $0.045 \mathrm{nmol} \mathrm{L}^{-1}$. The analytical reproducibility was determined to be $\pm 4 \%(n=7)$ at a $\mathrm{CH}_{4}$ concentration $\left(\left[\mathrm{CH}_{4}\right]\right)$ of $\sim 5 \mathrm{nmol} \mathrm{L}^{-1}$. The amount of photochemically produced $\mathrm{CH}_{4}$ was calculated as the difference in $\left[\mathrm{CH}_{4}\right]$ between the irradiated sample and the parallel dark control.

Absorbance spectra were recorded at room temperature from 600 to $280 \mathrm{~nm}$ at $1 \mathrm{~nm}$ intervals using a PerkinElmer lambda-35 dual beam UV-visible spectrometer fitted with $1 \mathrm{~cm}$ quartz cells and referenced to Nanopure water. The sample cell was rinsed with methanol, pure water, and sample water between individual scans. A baseline correction was applied by subtracting the absorbance value averaged over $683-687 \mathrm{~nm}$ from all spectral values (Babin et al., 2003). The Napierian absorption coefficient of $\mathrm{CDOM}$ at wavelength $\lambda, a_{\mathrm{CDOM}}(\lambda)\left(\mathrm{m}^{-1}\right)$, was calculated as 2.303 times the absorbance divided by the cell's light path length in meters. The lower detection limit of the absorption coefficient measurement, defined as three times the standard deviation of five replicate analyses of pure water was $0.02 \pm 0.01 \mathrm{~m}^{-1}$ over $280-600 \mathrm{~nm}$. DOC samples were acidified to $\mathrm{pH} \sim 2$ with $2 \mathrm{~N} \mathrm{HCl}$ to remove the dissolved inorganic carbon and analyzed in triplicate using a Shimadzu TOC-Vcpn carbon analyzer calibrated with potassium biphthalate. The system was checked, at intervals of seven consecutive sample analyses, against Hansell's low-carbon and deep Florida Strait $(700 \mathrm{~m})$ reference waters with DOC concentrations ([DOC]s) of $1 \mu \mathrm{mol} \mathrm{L}^{-1}$ and $41-44 \mu \mathrm{mol} \mathrm{L}^{-1}$, respectively. The coefficient of variation on five replicate injections was $<1.5 \%$. $\left[\mathrm{O}_{2}\right]$ was measured with a WTW Oxi 340 meter equipped with a CellOX 325 oxygen sensor (analytical accuracy: $\pm 0.5 \%$ ). A Thermo Orion $\mathrm{pH}$ meter (model 420A) fitted with a Ross Orion combination electrode was used to determine $\mathrm{pH}$; the system was standardized with three NIST buffers at $\mathrm{pH} 4.01,7.00$, and 10.01 .

\subsection{Calculations of absorbed photons and AQYs}

The photon flux absorbed by CDOM, $Q_{\mathrm{CDOM}}(\lambda)$ (mol photons $\mathrm{s}^{-1} \mathrm{~nm}^{-1}$ ), was calculated according to Hu et al. (2002):

$$
\begin{aligned}
Q_{\mathrm{CDOM}}(\lambda)= & Q_{0}(\lambda) \times\left(a_{\mathrm{CDOM}}(\lambda) / a_{\mathrm{t}}(\lambda)\right) \\
& \times S \times\left[1-\exp \left(-a_{t}(\lambda) \times L\right] .\right.
\end{aligned}
$$

$Q_{0}(\lambda)$ is the photon flux reaching the water surface inside the quartz cell (mol photons $\mathrm{m}^{-2} \mathrm{~s}^{-1} \mathrm{~nm}^{-1}$ ). The attenuation of light by the thin water layer above the cell $(\sim 2 \mathrm{~mm})$ was negligible $(<0.05 \%$ from $280-600 \mathrm{~nm})$. Here $a_{t}(\lambda)\left(\mathrm{m}^{-1}\right)$ is the sum of $a_{\mathrm{CDOM}}(\lambda)$ and the absorption coefficient of pure water obtained from Pope and Fry (1997) and Buiteveld et al. (1994). $S$ is the longitudinal cross section of the irradiation cell $\left(0.0055 \mathrm{~m}^{2}\right)$ and $L$ is the light pathlength of the cell, calculated as the squared root of the latitudinal cross section of the cell $(0.0193 \mathrm{~m})$, according to Osburn et al. (2001). Here $a_{\mathrm{CDOM}}(\lambda)$ is the exponential-based average of two adjacent irradiation time points, since photobleaching approximately follows first-order kinetics (Del Vecchio and Blough, 2002; also see Sect. 3.1). AQYs of photomineralization (AQY ${ }_{\mathrm{DOC}}$ in mol DOC (mol photons) ${ }^{-1}$ ) and photomethanification $\left(\mathrm{AQY}_{\mathrm{CH}_{4}} \text { in } \mathrm{mol} \mathrm{CH}_{4} \text { (mol photons) }\right)^{-1}$ ) were calculated as the rates of DOC loss and $\mathrm{CH}_{4}$ production divided by the rate of photons absorbed by CDOM (i.e. $Q_{\mathrm{CDOM}}(\lambda)$ in Eq. 1) integrated over the wavelength ranges of interest. Broadband AQYs were computed over $280-600 \mathrm{~nm}$ for full-spectrum time series irradiations and over UVB (280$320 \mathrm{~nm})$, UVA (320-400 nm), and VIS (400-600 nm) for irradiations evaluating the spectral quality effect.

\section{Results and discussion}

\subsection{Photochemical $\mathrm{O}_{2}$ consumption, bleaching, and acidification}

Figure 3 shows the time-course variations of $\left[\mathrm{O}_{2}\right], \mathrm{pH}$, the absorption coefficient at $330 \mathrm{~nm}\left(a_{\mathrm{CDOM}}(330)\right)$, and the spectral slope ratio $\left(S_{\mathrm{R}}\right)$ defined as the ratio of the spectral slope coefficient between 275 and $295 \mathrm{~nm}$ to that between 350 and $400 \mathrm{~nm}$. $S_{\mathrm{R}}$ has been used to characterize the source, molecular size, and photoprocessing of CDOM (Helms et al., 2008). Consistent with the results of previous studies (Gao and Zepp, 1998; Xie et al., 2004; Lou and Xie, 2006), irradiation led to photochemical $\mathrm{O}_{2}$ consumption, absorbance bleaching, and acidification (i.e. decrease in $\mathrm{pH}$ ). The temporal trends of these variables can be well described by 3-parameter exponential decay equations (Table 1). At the end of irradiations, $\left[\mathrm{O}_{2}\right]$ decreased 
Table 1. Fitted parameters for function $y=a+b \times \exp (-c \times x)$, where $x$ is irradiation time in hours. $F \_\mathrm{O}_{2}$ stands for fraction of dissolved $\left[\mathrm{O}_{2}\right]$. [DOC] and $\left[\mathrm{O}_{2}\right]$ are in $\mu \mathrm{mol} \mathrm{L}^{-1}$, and $a_{\mathrm{CDOM}}(330)$ in $\mathrm{m}^{-1}$.

\begin{tabular}{|c|c|c|c|c|c|c|c|c|c|c|c|c|}
\hline \multirow{2}{*}{$y$} & \multicolumn{4}{|c|}{$\mathrm{O}_{2}$ treatment } & \multicolumn{4}{|c|}{ Air treatment } & \multicolumn{4}{|c|}{$\mathrm{N}_{2}$ treatment } \\
\hline & $a$ & $b$ & $c$ & $R^{2}$ & $a$ & $b$ & $c$ & $R^{2}$ & $a$ & $b$ & $c$ & $R^{2}$ \\
\hline DOC & 315.4 & 269.8 & 0.0051 & 0.987 & 427.5 & 155.7 & 0.0108 & 0.997 & 506.9 & 72.9 & 0.0277 & 0.992 \\
\hline$a_{\mathrm{CDOM}}(330)$ & 2.69 & 21.63 & 0.011 & 0.994 & 9.83 & 14.63 & 0.0174 & 0.999 & 17.4 & 6.95 & 0.0252 & 0.998 \\
\hline $\mathrm{pH}$ & 6.17 & 1.10 & 0.0097 & 0.963 & 6.39 & 0.828 & 0.0237 & 0.996 & 6.67 & 0.542 & 0.060 & 0.908 \\
\hline$F \_\mathrm{O}_{2}$ & 0.834 & 0.170 & 0.0095 & 0.935 & 0.528 & 0.463 & 0.0136 & 0.992 & 0.800 & 0.200 & 0.0596 & 0.980 \\
\hline Initial $\left[\mathrm{O}_{2}\right]$ & \multicolumn{4}{|c|}{1023.0} & \multicolumn{4}{|c|}{271.2} & \multicolumn{4}{|c|}{53.1} \\
\hline
\end{tabular}

to $153.2 \mu \mathrm{mol} \mathrm{L}-1,890.6 \mu \mathrm{mol} \mathrm{L}-1$, and $42.2 \mu \mathrm{mol} \mathrm{L}^{-1}$ in the air, $\mathrm{O}_{2}$, and $\mathrm{N}_{2}$ treatments, respectively. The drop of $\left[\mathrm{O}_{2}\right]$ in the $\mathrm{N}_{2}$-treatment occurred entirely within the first $48 \mathrm{~h}$ (Fig. 3a). These final $\mathrm{O}_{2}$ concentrations indicate that oxic conditions were maintained in the air and $\mathrm{O}_{2}$ treatments throughout the irradiations while suboxic conditions persisted in the $\mathrm{N}_{2}$-treatment. CDOM absorbance decreased throughout the UV and VIS regimes (Fig. 4), fastest in the $\mathrm{O}_{2}$-treatment followed sequentially by the air and $\mathrm{N}_{2}$ treatment (Figs. 3b, 4), corroborating earlier findings (Gao and Zepp, 1998; Lou and Xie, 2006). The $a_{\mathrm{CDOM}}$ (330) declined by 75,56 , and $28 \%$ over the entire exposure period in the $\mathrm{O}_{2-}$, air, and $\mathrm{N}_{2}$ treatment, respectively. $S_{\mathrm{R}}$ continuously increased over the entire irradiation period in the air and $\mathrm{O}_{2}$ treatments; $S_{\mathrm{R}}$ in the $\mathrm{N}_{2}$-treatment increased with irradiation time up to $\sim 120 \mathrm{~h}$ and became stable thereafter (Fig. 3c), suggesting a complete exhaustion of $\mathrm{O}_{2}$. Notably, the changes in $S_{\mathrm{R}}$ for the three different $\mathrm{O}_{2}$ levels nearly lined up together during the first $24 \mathrm{~h}$ irradiation but started diverging at $\sim 48 \mathrm{~h}$ when $\left[\mathrm{O}_{2}\right]$ in the $\mathrm{N}_{2}$-treatment dropped to a constant level (Fig. 3a). The $\mathrm{pH}$ in the air treatment remained constantly below that in the $\mathrm{O}_{2}$-treatment except near the end of irradiation where the two converged at a similar $\mathrm{pH}$ value of $\sim 0.8$ unit below the initial level (Fig. $3 \mathrm{~d}$ ). The $\sim 0.5$ unit drop of $\mathrm{pH}$ in the $\mathrm{N}_{2}$-treatment took place largely within the initial $48 \mathrm{~h}$, echoing the behavior of $\left[\mathrm{O}_{2}\right]$. The tests utilizing different light filters indicate that photochemical $\mathrm{O}_{2}$ consumption, bleaching, and acidification decreased successively with the spectral composition of the incident light changing from UVB to UVA to VIS (Table 2), which conforms to the results of Lou and Xie (2006).

\subsection{Photomineralization}

Note that photochemical DOC loss leads to production of $\mathrm{CO}_{2}$ (in the form of dissolved inorganic carbon, DIC) and carbon monoxide (CO), with DIC being the main product (Miller and Zepp, 1995). As photomineralization rates reported in this study were equated to DOC loss rates, the former also included the $\mathrm{CO}$ component. Based on our unpublished AQY spectrum for CO photoproduction from CDOM in Saguenay River surface water $\left(\mathrm{AQY}_{\mathrm{CO}}(\lambda)=3.07 \times 10^{-10}\right.$

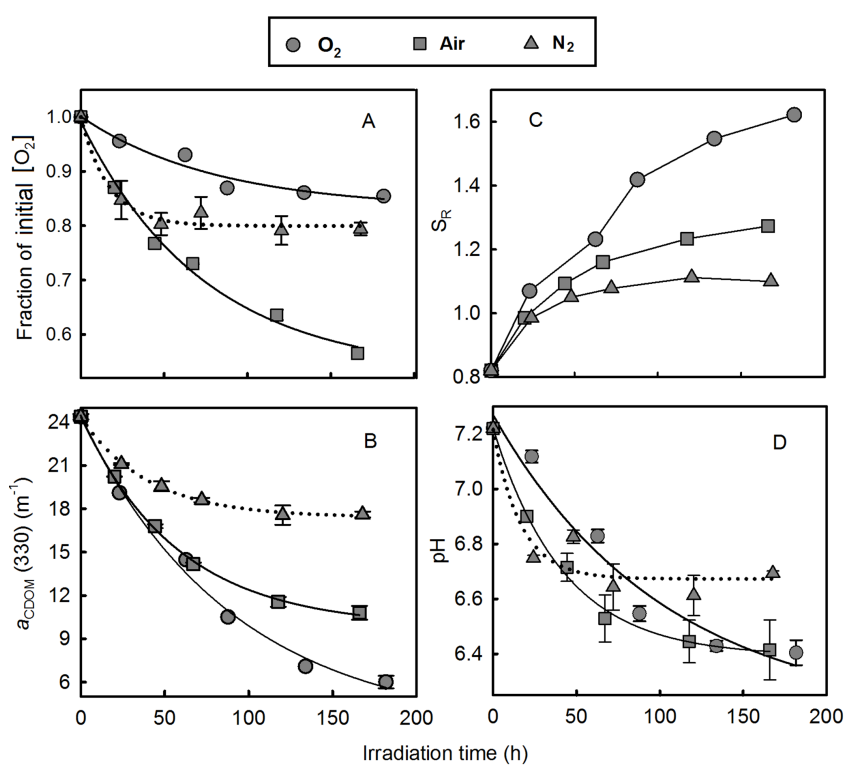

Figure 3. Fraction of initial dissolved $\left[\mathrm{O}_{2}\right](\mathbf{a}), a_{\mathrm{CDOM}}(330)$ (b), $S_{\mathrm{R}}(\mathbf{c})$, and $\mathrm{pH}(\mathbf{d})$ vs. irradiation time.

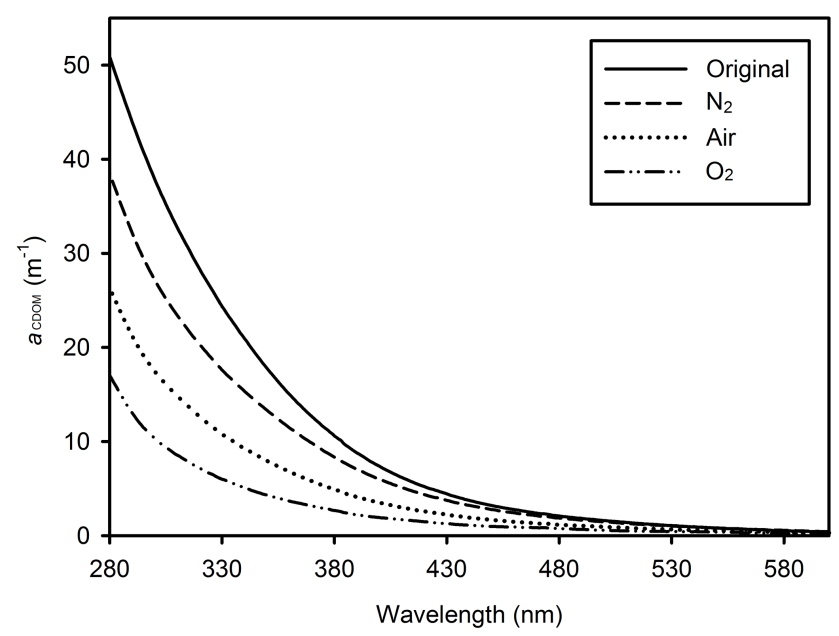

Figure 4. Comparison of absorption spectra before and after fullspectrum irradiations. 
Table 2. AQYs of DOC and $\mathrm{CH}_{4}$ and rates of $a_{\mathrm{CDOM}}(330)$ loss, $\mathrm{O}_{2}$ consumption and $\mathrm{pH}$ decrease under three light regimes (UVB, UVA, and VIS) in air and $\mathrm{N}_{2}$ treatments. Values are in mean \pm SD.

\begin{tabular}{llrrrrr}
\hline & & $\begin{array}{r}\mathrm{AQY}_{\mathrm{DOC}} \\
\left(\times 10^{-4}\right)\end{array}$ & $\begin{array}{r}\mathrm{AQY}_{\mathrm{CH}_{4}} \\
\left(\times 10^{-9}\right)\end{array}$ & $\begin{array}{r}a_{\mathrm{CDOM}(330)} \text { loss } \\
\left(\mathrm{m}^{-1} \mathrm{~h}^{-1}\right)\end{array}$ & $\begin{array}{r}\mathrm{O}_{2} \text { loss } \\
\left(\mu \mathrm{mol} \mathrm{L}^{-1} \mathrm{~h}^{-1}\right)\end{array}$ & $\begin{array}{r}\mathrm{pH} \text { decrease } \\
\left(\times 10^{-3} \mathrm{~h}^{-1}\right)\end{array}$ \\
\hline Air & UVB & $72.1 \pm 4.74$ & $38.9 \pm 2.01$ & $0.13 \pm 0.005$ & $1.67 \pm 0.11$ & $2.76 \pm 0.35$ \\
& UVA & $6.24 \pm 0.36$ & $3.55 \pm 0.24$ & $0.06 \pm 0.004$ & $0.45 \pm 0.10$ & $1.61 \pm 0.23$ \\
& VIS & $0.93 \pm 0.06$ & $0.42 \pm 0.02$ & $0.03 \pm 0.003$ & $0.02 \pm 0.01$ & $0.69 \pm 0.08$ \\
\hline $\mathrm{N}_{2}$ & UVB & $28.2 \pm 1.50$ & $372.7 \pm 8.9$ & $0.14 \pm 0.005$ & $1.12 \pm 0.04$ & $1.47 \pm 0.82$ \\
& UVA & $4.19 \pm 0.90$ & $12.76 \pm 1.24$ & $0.09 \pm 0.002$ & $0.25 \pm 0.05$ & $1.23 \pm 0.18$ \\
& VIS & $0.77 \pm 0.03$ & $0.67 \pm 0.05$ & $0.05 \pm 0.004$ & $0.15 \pm 0.03$ & $0.51 \pm 0.27$ \\
\hline
\end{tabular}

$\exp (5661 /(149.1+\lambda))$, where $\lambda$ is wavelength in nanometers), we estimated that the ratio of DIC to CO photoproduction was 30.8. Photomineralization was thus overwhelmingly dominated by DIC production in our study.

\subsubsection{Effect of $\left[\mathrm{O}_{2}\right]$}

[DOC] decreased exponentially with irradiation time as well (Fig. 5a and Table 1). The differences among the three $\mathrm{O}_{2}$ treatments were rather small during the first $48 \mathrm{~h}$ and thereafter [DOC] in the $\mathrm{N}_{2}$-treatment rapidly stabilized while [DOC] in the air and $\mathrm{O}_{2}$ treatments continued to decline. Hence, $\left[\mathrm{O}_{2}\right]$ in the $\mathrm{N}_{2}$-treatment was a limiting factor of photomineralization until $\left[\mathrm{O}_{2}\right]$ decreased to a stable level (Fig. 5a). Notably, the difference in the rate of [DOC] drawdown between the air and $\mathrm{O}_{2}$ treatment was much smaller than that for $a_{\mathrm{CDOM}}$ (330) (Fig. 3b), demonstrating that photobleaching was far more sensitive to $\left[\mathrm{O}_{2}\right]$ than photomineralization. While the temporal trends of [DOC] were exponential, $[\mathrm{DOC}]$ decreased linearly with absorbance photobleaching, with the slope becoming progressively steeper towards deceasing initial $\left[\mathrm{O}_{2}\right]$ (Fig. 5b). A closer examination of the data indicates that the ratio of the fractional DOC loss to the fractional $a_{\mathrm{CDOM}}(330)$ loss decreased from 0.82 in the $\mathrm{N}_{2}$-treatment to 0.64 in the air treatment to 0.54 in the $\mathrm{O}_{2}$-treatment (Fig. 5c). Similar results were obtained at the wavelengths of 254,300 , and $400 \mathrm{~nm}$ (data not shown). Therefore, photochemical DOC loss proceeded more efficiently under $\mathrm{O}_{2}$-deficiency than under oxic conditions on a per- $a_{\mathrm{CDOM}}-$ loss basis, opposite to the trend of the time-based DOC loss rate. In other words, higher fractions of CDOM were mineralized under $\mathrm{O}_{2}$-depletion than under oxygenation.

\subsubsection{Apparent quantum yields}

AQY DOC decreased exponentially $\left(R^{2}=0.969\right)$ in the $\mathrm{N}_{2}$-treatment and remained nearly constant $\left(1.50 \times 10^{-4} \pm 0.05 \times 10^{-4}\right)$ in the air treatment with respect to photobleaching (Fig. 5d). In the $\mathrm{O}_{2}$-treatment, $\mathrm{AQY}$ DOC was invariable initially (up to $23 \%$ loss of $\left.a_{\mathrm{CDOM}}(330)\right)$ and then increased linearly $\left(R^{2}=0.965\right)$
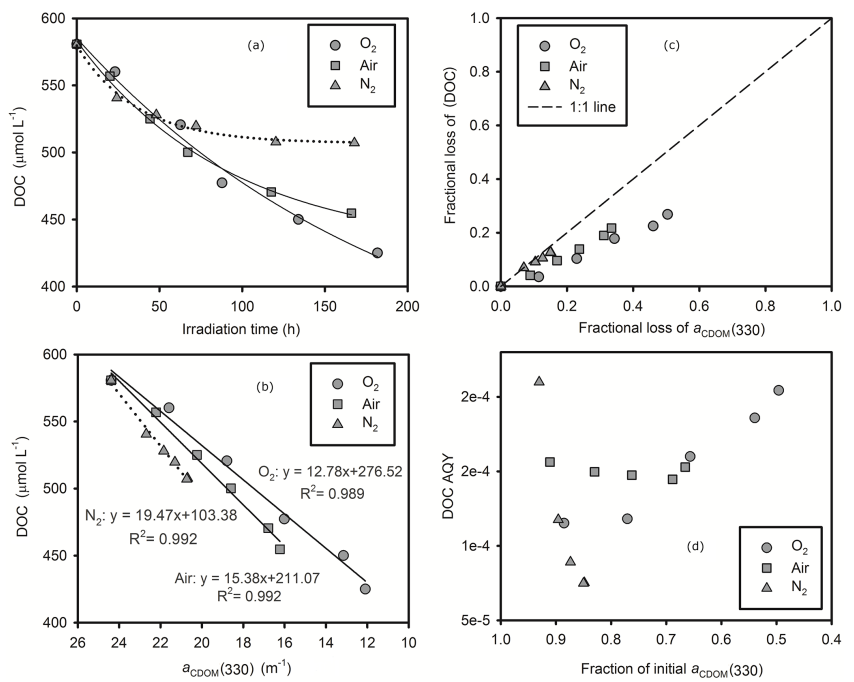

Figure 5. [DOC] vs. irradiation time (a) and $a_{\mathrm{CDOM}}(330)$ (b), fractional loss of [DOC] vs. fractional loss of $a_{\mathrm{CDOM}}(330)$ (c), and AQY $Y_{\text {DOC }}$ vs. fraction of initial $a_{\mathrm{CDOM}}(330)$ (d). Lines in panels $\mathrm{A}$ and $\mathrm{B}$ are best fits of the data. Fitted equations for panel $\mathrm{A}$ are presented in Table 1.

with further photobleaching. The decrease of $A Q Y_{D O C}$ with photobleaching in the $\mathrm{N}_{2}$-treatment suggests that the removal of DIC precursors was faster than the bleaching of CDOM under $\mathrm{O}_{2}$ deficiency. Conversely, the results from the $\mathrm{O}_{2}$ - and air treatments imply that under oxic conditions the removal of DIC precursors was slower than or similar to the bleaching of CDOM or that DIC precursors were regenerated during irradiation. Although the mechanism of photoproduction of DIC is not well understood, photodecarboxylation is considered to be involved (Miles and Brezonik, 1981). However, Xie et al. (2004) found that neither the initial content nor the apparent loss of carboxylic groups on DOM could account for the amount of DIC produced during an extensive photobleaching of a Satilla River water sample. These authors thus proposed that carboxylic groups are photochemically regenerated if photodecarboxylation is the predominant pathway for DIC production. The trends of 
AQY ${ }_{\text {DOC }}$ vs. photobleaching observed under oxic conditions in the present study are thus consistent with the supposition of Xie et al. (2004). Furthermore, the decrease in pH (see Sect. 3.1) indicates the formation of acidic photoproducts during irradiation. Although the production of $\mathrm{CO}_{2}$ (in the form of DIC) could have contributed a large part to the $\mathrm{pH}$ decline, carboxylic acids are also known photoproducts of CDOM (Moran and Zepp, 1997).

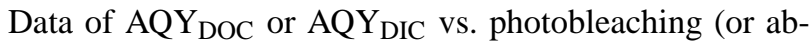
sorbed doses) are scarce. Previous studies on $A Q Y_{D O C}$ or $A Q Y_{\text {DIC }}$ often employed short-term irradiations that led to minor losses of $a_{\mathrm{CDOM}}$ (e.g. Johannessen and Miller, 2001; Reader and Miller, 2012). Results from the present study are pertinent to medium-term exposures (up to $56 \%$ loss of $a_{\mathrm{CDOM}}(330)$ in the air treatment). The relatively invariable $A Q Y_{D O C}$ across this photobleaching regime suggests that $A Q Y_{D O C}$ data obtained from short-term irradiations are applicable to modeling photomineralization fluxes in the Saguenay River over medium-term exposures. Over long-term exposures approaching a complete loss of $a_{\text {CDOM }}$, Vähätalo and Wetzel (2004) observed a decrease in $\mathrm{AQY}_{\mathrm{DOC}}$ with photobleaching for water collected from Lake Tuscaloosa in Alabama. It remains to be elucidated if the same is true for the Saguenay River.

The irradiations employing light filters allowed us to evaluate the effect of light quality on $\mathrm{AQY}_{\mathrm{DOC}}$. As shown in Table 2, AQY ${ }_{\mathrm{DOC}}$ obtained from the air treatment decreased by $\sim 12$ times from UVB to UVA and further by 7 times from UVA to VIS. The spectral dependence of $A Q Y_{D O C}$ was lower for the $\mathrm{N}_{2}$-treatment; $\mathrm{AQY} \mathrm{DOC}_{\mathrm{DOC}}$ in UVB was $\sim 7$ times that in UVA, which in turn was $\sim 5$ times that in VIS. The flatter spectral dependence under the $\mathrm{N}_{2}$ - relative to air treatment could be related to different prevailing mechanisms for photomineralization, e.g. direct photodecarboxylation under the $\mathrm{N}_{2}$-treatment vs. secondary photoprocesses initiated by reactive oxygen species produced in the presence of molecular oxygen (Frimmel, 1994).

Full spectrum-based AQY ${ }_{\text {DOC }}$ obtained from the air treatment in our study match closely those in Valkea-Kotinen lake $\left(1.37 \times 10^{-4}\right.$, derived from 300 to $700 \mathrm{~nm}$, Vähätalo et al., 2000) and Pääjärvi lake $\left(1.21 \times 10^{-4}\right.$, derived from 190 to $800 \mathrm{~nm}$, Aarnos et al., 2012) but an order lower than that in the Mackenzie river freshwater $\left(1.0 \times 10^{-3}-3.0 \times 10^{-3}\right.$, derived from $280 \mathrm{~nm}$ to $500 \mathrm{~nm}$, Osburn et al., 2009) and $\sim 3$ times higher than that in the northern shelf in the Gulf of Mexico $\left(5.6 \times 10^{-6}\right.$, derived from 290 to $490 \mathrm{~nm}$, Fichot and Benner, 2014). The difference may be attributed to the variation of photoreactivity of CDOM in different water bodies or different wavelength range for obtaining the AQY or both.

\subsubsection{Implication for DOC cycling in the Saguenay River}

Assuming negligible backscattering of light from the water column to the atmosphere, the depth-integrated photochem- ical DOC loss rate $\left(P_{\mathrm{DOC}}, \mathrm{mol} \mathrm{Cm}^{-2} \mathrm{~d}^{-1}\right)$ in the euphotic zone of the Saguenay River can be calculated as

$P_{\mathrm{DOC}}=Q \times \alpha_{r} \times R_{\mathrm{a}} \times \mathrm{AQY}_{\mathrm{DOC}}$,

where $Q$ (mol photons $\mathrm{m}^{-2} \mathrm{~d}^{-1}$ ) is the global solar photon flux $(280-600 \mathrm{~nm})$ under clear-sky conditions at latitude $48.4^{\circ} \mathrm{N}$ and is generated from the SMARTS2 model (Gueymard, 1995, 2001); $\alpha_{r}$ is the combination of two correction factors for reflection of light by cloud (0.8) and at the air-water interface (0.93) (Stubbins et al., 2006), and $R_{\mathrm{a}}$ is the fraction of light absorbed by CDOM in the photic zone, which is assumed to be 0.80 and vertically constant (Xie et al., 2012). AQY ${ }_{\text {DOC }}$ is the broadband $(280-600 \mathrm{~nm})$ photomineralization quantum yield determined during this study under the air treatment $\left(1.50 \times 10^{-4} \pm 0.15 \times 10^{-4}\right)$ and is assumed to be seasonally constant. $\mathrm{P}_{\mathrm{DOC}}$ was estimated to be $(2.97 \pm 0.30) \times 10^{-3} \mathrm{~mol} \mathrm{C} \mathrm{m}^{-2} \mathrm{~d}^{-1}$ in spring, $(3.67 \pm 0.37) \times 10^{-3} \mathrm{~mol} \mathrm{C} \mathrm{m}^{-2} \mathrm{~d}^{-1}$ in summer, $\quad(1.71 \pm 0.17) \times 10^{-3} \mathrm{~mol} \mathrm{C} \mathrm{m}^{-2} \mathrm{~d}^{-1}$ in autumn, $(1.11 \pm 0.11) \times 10^{-3} \mathrm{~mol} \mathrm{C} \mathrm{m}^{-2} \mathrm{~d}^{-1}$ in winter. These values yield an annual rate of $0.77 \mathrm{~mol} \mathrm{C} \mathrm{m}^{-2}$, excluding icecovered areas in spring (ice coverage: 0.11 ) and winter (ice coverage: 0.65 ) calculated from the 1971-2000 Canadian Ice Service database (CIS, 2001). Combining the estimates of $\mathrm{P}_{\mathrm{DOC}}$ with the area of the Saguenay River $\left(300 \mathrm{~km}^{2}, 100 \mathrm{~km}\right.$ long $\times 3 \mathrm{~km}$ wide) gives an annual rate of DOC photomineralization of $2.31 \times 10^{8} \mathrm{molC}$. Based on the [DOC] near Chicoutimi $\left(\sim 583.3 \mu \mathrm{mol} \mathrm{L}{ }^{-1}\right.$, this study and Tremblay and Gagné, 2009) and a yearly averaged freshwater discharge of $1194 \mathrm{~m}^{3} \mathrm{~s}^{-1}$ (Bélanger, 2003), the annual DOC input to the Saguenay River was calculated as $2.20 \times 10^{10} \mathrm{~mol} \mathrm{C}$. DOC photomineralization thus accounts for $1 \%$ of the annual DOC input. The majority of photomineralization of CDOM from the Saguenay River is expected to take place after the CDOM is transported to the lower St. Lawrence estuary and the Gulf of St. Lawrence, where it will be strongly diluted and thus experience more efficient photooxidation.

The spectral dependence data of AQY ${ }_{D O C}$ (Table 2), combined with Eq. (2), allowed us to evaluate the relative contributions of UVB, UVA, and VIS to the full-spectrum, depthintegrated photomineralization rate, arriving at 15, 41, and $44 \%$, respectively, for the air treatment. Hence, VIS and UVA are the dominant contributors while UVB is the least important.

\subsection{Photomethanification}

\subsubsection{Effect of $\left[\mathrm{O}_{2}\right]$}

$\left[\mathrm{CH}_{4}\right]$ increased linearly with irradiation time (Fig. 6a), absorbance photobleaching (Fig. 6b), and DOC loss (Fig. 6c) under the air and $\mathrm{O}_{2}$ treatments. While the time-based rate of $\mathrm{CH}_{4}$ photoproduction under the air treatment (4.3 pmol L ${ }^{-1} \mathrm{~h}^{-1}$ ) was only $10 \%$ higher than under the $\mathrm{O}_{2}$ treatment $\left(3.9 \mathrm{pmol} \mathrm{L}^{-1} \mathrm{~h}^{-1}\right)$, the $a_{\mathrm{CDOM}}(330)$ - and [DOC]- 

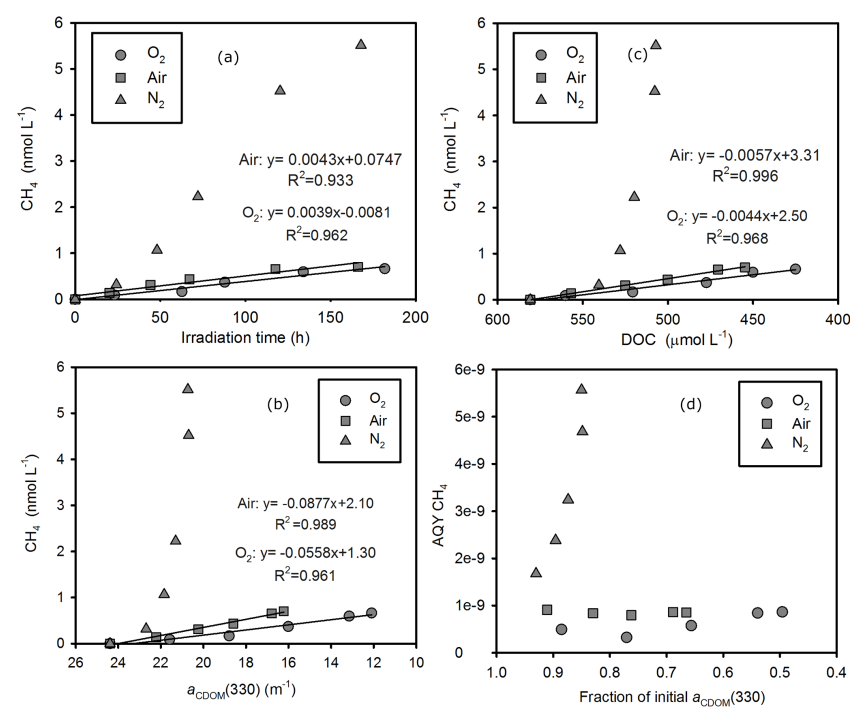

Figure 6. $\left[\mathrm{CH}_{4}\right]$ vs. irradiation time (a), $a_{\mathrm{CDOM}}(330)$ (b) and [DOC] (c), and AQY $\mathrm{CH}_{4}$ vs. fraction of initial $a_{\mathrm{CDOM}}(330)$ (d). Lines in panels (a), (b) and (c) are best fits of the data.

based rates differed by $57 \%$ ( 88 vs. $\left.56 \mathrm{pmol} \mathrm{L}^{-1} \mathrm{~m}\right)$ and $30 \%$ (5.7 vs. $\left.4.4 \mathrm{pmol} \mathrm{CH}_{4}(\mu \mathrm{molDOC})^{-1}\right)$, respectively. $\left[\mathrm{CH}_{4}\right]$ in the $\mathrm{N}_{2}$-treatment increased sharply after an initial slow increment (Fig. 6a-c) that corresponded to a major reduction of the residual $\left[\mathrm{O}_{2}\right]$ (Fig. 3a). The time-based production rate of $\mathrm{CH}_{4}$ in the $\mathrm{N}_{2}$-treatment decreased when approaching the end of irradiation (Fig. 6a), whereas the $a_{\mathrm{CDOM}}(330)-$ and [DOC]-based rates continuously grew over the entire exposure period (Fig. 6b, c). The time-course mean $\mathrm{CH}_{4}$ production rate in the $\mathrm{N}_{2}$-treatment $\left(32 \mathrm{pmol} \mathrm{L}^{-1} \mathrm{~h}^{-1}\right)$ was 7.4 times that in the air treatment and 8.2 times that in the $\mathrm{O}_{2}$-treatment. The corresponding ratios increased to 56 and 88 on a per- $a_{\mathrm{CDOM}}(330)$ basis and 17 and 23 on a per-[DOC] basis.

Our results demonstrate that photomethanification is strongly favored under $\mathrm{O}_{2}$-deficiency but also occurs under oxygenated conditions. This observation somewhat differs from that of Bange and Uher (2005) showing undetectable $\mathrm{CH}_{4}$ photoproduction under oxic conditions but significant production under anoxia in the presence of millimolar levels of acetone, a methyl $\left(\mathrm{CH}_{3}\right)$ radical precursor. Bange and Uher (2005) proposed that photomethanification involves the formation of $\mathrm{CH}_{3}$ radicals from CDOM-mediated photosensitized processes, followed by $\mathrm{H}$-abstraction by $\mathrm{CH}_{3}$ radicals from a variety of potential substrates. These authors further reasoned that because of the reaction of dissolved $\mathrm{O}_{2}$ with the $\mathrm{CH}_{3}$ radical (Neta et al., 1996), the H-abstraction by $\mathrm{CH}_{3}$ radicals, hence $\mathrm{CH}_{4}$ production, is greatly suppressed by high dissolved $\mathrm{O}_{2}$ concentrations. The different results between the two studies could thus have resulted from our sample containing more reactive $\mathrm{CH}_{3}$ radical precursors, substrates for $\mathrm{H}$-abstraction, and/or photosensitizing CDOM. It is also plausible that the $\mathrm{CH}_{4}$ production rates reported by Bange and Uher (2005) are underestimates due to residual microbial activity in their filtered samples.

\subsubsection{Apparent quantum yields}

$\mathrm{AQY}_{\mathrm{CH}_{4}}$ in the air treatment $\left(8.5 \times 10^{-10} \pm 0.4 \times 10^{-10}\right)$ changed little with photobleaching but increased exponentially $\left(R^{2}=0.963\right)$ in the $\mathrm{N}_{2}$-treatment (range: $1.7-$ $5.6 \times 10^{-9}$; mean: $3.5 \times 10^{-9}$ ) (Fig. $6 \mathrm{~d}$ ). $\mathrm{AQY}_{\mathrm{CH}_{4}}$ in the $\mathrm{O}_{2}$-treatment varied between $3.2 \times 10^{-10}$ and $8.6 \times 10^{-10}$ (mean: $5.6 \times 10^{-10} \pm 2.2 \times 10^{-10}$ ) with the later irradiation stage giving relatively higher values than the earlier stage. On average, $\mathrm{AQY} \mathrm{CH}_{4}$ was 4 times higher in the $\mathrm{N}_{2}$-treatment than in the air treatment, which in turn was $53 \%$ higher than in the $\mathrm{O}_{2}$-treatment. At the end of irradiation, $\mathrm{AQY} \mathrm{CH}_{4}$ in the $\mathrm{N}_{2}$-treatment was 6.6 times that in the air treatment. The rapid increases in $\mathrm{CH}_{4}$ production (Fig. $6 \mathrm{~b}$ ) and $\mathrm{AQY} \mathrm{CH}_{4}$ (Fig. 6d) with photobleaching in the $\mathrm{N}_{2}$-treatment likely resulted from a continuing depletion of the residual $\mathrm{O}_{2}$ in that sample. It should be noted that the stabilization of $\left[\mathrm{O}_{2}\right]$ at $42.2 \mu \mathrm{mol} \mathrm{L}-1$ towards the end of irradiation in the $\mathrm{N}_{2}$ treatment (Sect. 3.1) could be ascribed to an ingress of $\mathrm{O}_{2}$ from ambient air during sample transfer for $\left[\mathrm{O}_{2}\right]$ determination, as alluded in Sect. 2.2. This artifact could have masked the decline of $\left[\mathrm{O}_{2}\right]$.

Similar to the spectral dependence of AQY also decreased sequentially from UVB to UVA to VIS for both the air and $\mathrm{N}_{2}$ treatments (Table 2). However, $A Q Y_{\mathrm{CH}_{4}}$ was strongly skewed towards UVB under the $\mathrm{N}_{2}$ treatment.

\subsubsection{DMS as a precursor of $\mathrm{CH}_{4}$}

An addition of $20 \mu \mathrm{mol} \mathrm{L}{ }^{-1}$ DMS increased the rate of $\mathrm{CH}_{4}$ photoproduction by $27-45 \%$ in the air treatment (Fig. 7a) and by $14-6400 \%$ in the $\mathrm{N}_{2}$-treatment (Fig. 7 b) over a time series irradiation of up to $166.3 \mathrm{~h}$. The difference between the DMS-amended and the original sample increased with irradiation time. Irradiation of samples containing varying DMS concentrations revealed a first-order kinetics of $\mathrm{CH}_{4}$ production with respect to [DMS] in the air treatment but a Michaelis-Menten type of kinetics in the $\mathrm{N}_{2}$-treatment, with the production rate in the $\mathrm{N}_{2}$-treatment 2 orders of magnitude higher than in the air treatment at $[\mathrm{DMS}]>20 \mu \mathrm{mol} \mathrm{L}^{-1}$ (Fig. 8).

The similar patterns of the $\mathrm{O}_{2}$ effect with and without the addition of DMS suggest that $\mathrm{CH}_{4}$ photoproduction from DMS may also proceed through the formation of $\mathrm{CH}_{3}$ radicals. DMS does not undergo direct photolysis, since it is transparent within the spectrum of solar radiation reaching the earth's surface (McDiarmid, 1974). However, DMS can be degraded by photosensitizing reactions, including those initiated by CDOM (Brimblecombe and Shooter, 1986). The saturation of $\mathrm{CH}_{4}$ production at elevated DMS concentrations in the $\mathrm{N}_{2}$-treatment (Fig. 8) could be interpreted as a 

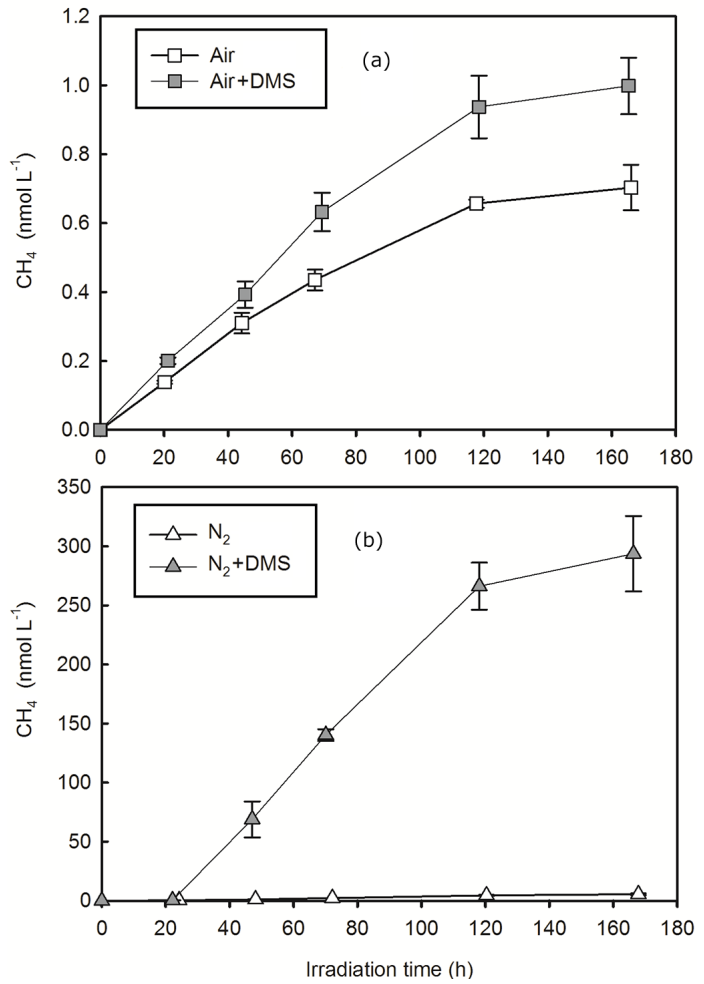

Figure 7. Effect of DMS spiking $\left(20 \mu \mathrm{mol} \mathrm{L}^{-1}\right)$ on $\mathrm{CH}_{4}$ photoproduction in a time series irradiation under air and $\mathrm{N}_{2}$ treatments (a, b).

limitation of the photosensitizing capacity of CDOM and/or the availability of substrates for $\mathrm{H}$-abstraction. Although the exact mechanism responsible for DMS photodegradation in natural waters is not well established, the $\mathrm{OH}$ radical is likely implicated (Bouillon and Miller, 2005; Williams et al., 2009). $\mathrm{OH}$ radicals in natural waters are produced from CDOM photochemistry (Mopper and Zhou, 1990) and photolysis of nitrate (Zafiriou and True, 1979) in the absence of $\mathrm{O}_{2}$, with an additional contribution from the (photo) Fenton reaction (Esplugas et al., 2002) in the presence of $\mathrm{O}_{2}$. As has been observed in gas-phase studies (Arsene et al., 2001), the reaction of the $\mathrm{OH}$ radical with DMS may produce the $\mathrm{CH}_{3}$ radical, though the dominant product of this reaction is DMSO in the presence of $\mathrm{O}_{2}$. The $\mathrm{CH}_{3}$ radical then abstracts a hydrogen atom from DMS itself (Arthur and Lee, 1976) or other compounds such as thios (Neta et al., 1996) to produce $\mathrm{CH}_{4}$. In brackish or saline waters, the formation of $\mathrm{CH}_{3}$ radicals may result from the reactions of DMS with the $\mathrm{Br}_{2}^{-}$and $\mathrm{CO}_{3}^{-}$radicals which are preferentially produced via the reactions of the HO radical with the bromide and carbonate and/or bicarbonate ions (True and Zafiriou, 1985). The involvement of the $\mathrm{CO}_{3}^{-}$in DMS oxidation has been confirmed by Bouillon and Miller (2005), though the individual steps of this process are unclear.

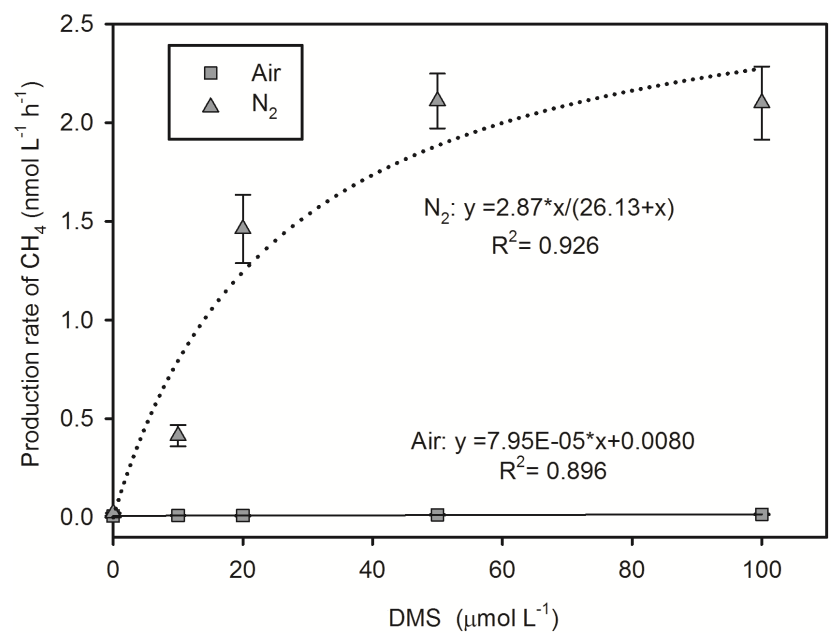

Figure 8. Photoproduction rate of $\mathrm{CH}_{4}$ as a function of added [DMS].

Given that dissolved DMS concentrations in sunlit, oxic surface waters are normally at nanomolar levels, it is unlikely that photodegradation of DMS can serve as a significant source of $\mathrm{CH}_{4}$ in the water column. However, cellular DMS concentrations have been observed to reach up to $1.5-30 \mathrm{mmol}$ (liter of cell volume) ${ }^{-1}$ (Sunda et al., 2007), translating to a $\mathrm{CH}_{4}$ production rate of $0.13-2.39 \mathrm{nmol}$ (liter of cell volume) $)^{-1} \mathrm{~h}^{-1}$ under otherwise identical conditions. Photooxidation of cellular DMS could thus provide a potentially significant source of $\mathrm{CH}_{4}$ to waters that abound with prolific DMS producers (e.g. Phaeocystis). In addition, cellular dimethylsulfoniopropionate (DMSP) is often more abundant than cellular DMS (Keller et al., 1989; Bucciarelli and Sunda, 2003) and therefore could also be a potentially important precursor of photoproduced $\mathrm{CH}_{4}$.

\subsubsection{Implication for $\mathrm{CH}_{4}$ cycling on regional and global scales}

The depth-integrated photomethanification rate $\left(P_{\mathrm{CH}_{4}}\right)$ in the Saguenay River can be estimated using Eq. (2) by substituting $\mathrm{AQY}_{\mathrm{CH}_{4}}$ for $\mathrm{AQY}$ DOC. Alternatively, it can be assessed by multiplying $P_{\mathrm{DOC}}$ by the slope of the fitted line for the air treatment in Fig. 6c (i.e. $0.00057 \%$ ). The former approach is adopted, arriving at $(1.69 \pm 0.08) \times 10^{-8} \mathrm{~mol} \mathrm{~m}^{-2} \mathrm{~d}^{-1}$ in spring, $\quad(2.08 \pm 0.10) \times 10^{-8} \mathrm{~mol} \mathrm{~m}^{-2} \mathrm{~d}^{-1}$ in summer, $\quad(9.70 \pm 0.48) \times 10^{-9} \mathrm{~mol} \mathrm{~m}^{-2} \mathrm{~d}^{-1}$ in fall, and $(6.33 \pm 0.31) \times 10^{-9} \mathrm{~mol} \mathrm{~m}^{-2} \mathrm{~d}^{-1}$ in winter. The annual total is calculated to be $4.36 \times 10^{-6} \mathrm{~mol} \mathrm{~m}^{-2}$ with $\mathrm{CH}_{4}$ photoproduction in ice-covered seasons ignored. It is not possible to compare the photoproduction rates with other $\mathrm{CH}_{4}$ cycling terms in the Saguenay River such as microbial production and consumption rates, and air-sea exchange fluxes, since the latter is unknown. The annual $\mathrm{CH}_{4}$ photoproduction rate obtained for the Saguenay River 
is, however, about $12 \%$ of the aerobic microbial $\mathrm{CH}_{4}$ consumption rate in the surface Black Sea (Schmale et al., 2011) but is generally many orders of magnitude lower than sea-air fluxes in various estuarine and coastal environments, which frequently reach tens to hundreds of $\mu \mathrm{mol} \mathrm{m}{ }^{-2} \mathrm{~d}^{-1}$ (Bange et al., 1994).

As was the case for DOC (Sect. 3.3.3), the percent contributions of the three major wavelength ranges to the fullspectrum, depth-integrated $\mathrm{CH}_{4}$ photoproduction were estimated using Eq. (2) along with the spectral dependence data of $\mathrm{AQY}_{\mathrm{CH}_{4}}$ (Table 2). For the air treatment, the contributions from UVA (39\%) and VIS (35\%) are similar while UVB only contributes $16 \%$. As the attenuation of UVA and VIS is much slower than UVB in the water column, $\mathrm{CH}_{4}$ photoproduction is expected to penetrate into relatively deep depths under oxic conditions. For the $\mathrm{N}_{2}$-treatment, the percent contribution follows a descending order of UVA $(43 \%)>$ UVB $(40 \%)>$ VIS $(17 \%)$, indicating that UVB is far more important than VIS under $\mathrm{O}_{2}$-depleted conditions.

Because the photomethanification efficiency of CDOM may change geographically, extrapolation of our results to other regions is speculative by nature. The current estimate of photodegradation of DOC in global open oceans ranges from 400-1700 $\mathrm{Tg} \mathrm{C} \mathrm{yr}^{-1}$ (Mopper et al., 2015), which exceeds the total riverine DOC input of $\sim 260 \mathrm{Tg} \mathrm{Cyr}^{-1}$ to global oceans (Raymond and Spencer, 2015). This DOC loss translates to a $\mathrm{CH}_{4}$ photoproduction rate of (1.9$8.1) \times 10^{8} \mathrm{~mol} \mathrm{yr}^{-1}$, assuming that the ratio of $\mathrm{CH}_{4}$ photoproduction to DOC loss $(0.00057 \%)$ observed for the air treatment in the present study is applicable to both riverine and marine DOC on global scales. These rates only account for $0.09-0.4 \%$ of the open-ocean $\mathrm{CH}_{4}$ efflux of $2.3 \times 10^{11} \mathrm{~mol} \mathrm{yr}^{-1}$ (Bange et al., 1994) and 0.07$0.3 \%$ of the net $\mathrm{CH}_{4}$ production of $2.3 \mu \mathrm{mol} \mathrm{m}^{-2} \mathrm{~d}^{-1}$ $\left(2.6 \times 10^{11} \mathrm{~mol} \mathrm{yr}^{-1}\right)$ that is required to sustain the $\mathrm{CH}_{4}$ supersaturation and outgassing loss in the upper $100 \mathrm{~m}$ of global open oceans (Reeburgh, 2007). However, our estimates of the $\mathrm{CH}_{4}$ photoproduction rates are significant compared to microbial $\mathrm{CH}_{4}$ oxidation rates in oxic open oceans that have been shown to be $0.15 \mathrm{nmol} \mathrm{L}^{-1} \mathrm{yr}^{-1}$ in waters of $<10$-years old (equivalent to $5.4 \times 10^{9} \mathrm{~mol} \mathrm{yr}^{-1}$ if scaled to the upper $100 \mathrm{~m}$ layer) and $10^{-4} \mathrm{nmol} \mathrm{L}^{-1} \mathrm{yr}^{-1}$ in aged waters (equivalent to $1.3 \times 10^{8} \mathrm{~mol} \mathrm{yr}^{-1}$ if scaled to waters deeper than $100 \mathrm{~m}$ ) (Reeburgh, 2007). Notably, our estimates do not take into account the $\mathrm{CH}_{4}$ that could be produced photochemically from anoxic and low-oxygen microenvironments present in decaying organic particles such as planktonic detritus and fecal pellets (Alldredge and Cohen, 1987). Since $\mathrm{AQY}_{\mathrm{CH}_{4}}$ under anoxic conditions is up to 7 times that at air saturation (Sect. 3.3.2) and since organic particles are likely more photoreactive than CDOM (Zafiriou, 2002), particularly at VIS wavelengths (Song et al., 2013), it is plausible that the particle-based $\mathrm{CH}_{4}$ photoproduction could be more important that the CDOM counterpart.
The present study demonstrates that $\mathrm{CH}_{4}$ photoproduction is favored by UVB under $\mathrm{O}_{2}$-deficiency. Given that the surface ocean in the Archean was anoxic before $\mathrm{O}_{2}$ accumulation in the atmosphere 2.32 billion years ago (Bekker et al., 2004) and that UVB in the Archean was $\sim 3$ times the present-day level (Cockell, 1998), the $\mathrm{CH}_{4}$ photoproduction rate in the Archean ocean can be approximately inferred from our results for the $\mathrm{N}_{2}$ treatment by summing 3 times the production under UVB, 1 time the production under UVA, and 1 time the production under VIS, giving $9.78 \times 10^{-8} \mathrm{~mol} \mathrm{CH}_{4} \mathrm{~m}^{-2} \mathrm{~d}^{-1}$. This value corresponds to only $0.7 \%$ of the $\mathrm{CH}_{4}$ flux density in the Archean $\left(1.47 \times 10^{-5} \mathrm{~mol} \mathrm{~m}^{-2} \mathrm{~d}^{-1}\right)$ that was required to maintain a $\mathrm{CH}_{4}$ mixing ratio of $100 \mathrm{ppm}$ in the Archean atmosphere (Bange and Uher, 2005). Note that this estimate is based on the assumption that $\mathrm{AQY} \mathrm{CH}_{4}$ and the fraction of solar radiation absorbed by CDOM in the Archean ocean were similar to those adopted in this study. It should also be pointed out that $\mathrm{N}_{2}$-purging must have depleted the volatile precursors of the methyl radical in our samples and that the Archean ocean likely contained higher concentrations of $\mathrm{CH}_{4}$ precursors such as acetone (Bange and Uher, 2005) than does the present ocean, thereby leading to an underestimate of $\mathrm{CH}_{4}$ photoproduction in the Archean ocean.

\section{Summary and future work}

Rates of photomineralization and photomethanification of CDOM from the Saguenay River were determined at three widely different $\left[\mathrm{O}_{2}\right] \mathrm{s}$ (suboxic, air-saturated, and oxygenated) over medium-term exposure to simulated solar radiation. Photomineralization increased linearly with absorbance photobleaching. While the photochemical DOC loss rate increased with increasing $\left[\mathrm{O}_{2}\right]$, the ratio of the fractional DOC loss to the fractional $a_{\mathrm{CDOM}}$ loss trended oppositely. Photochemical breakdown of CDOM led to a higher degree of mineralization (i.e. DIC production) under suboxic conditions than under oxic conditions. $\mathrm{AQY}_{\mathrm{DOC}}$ increased, decreased, and remained fairly constant with photobleaching under oxygenated, suboxic, and air-saturated con-

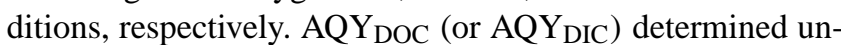
der air saturation with short-term irradiations can be applied to medium-term exposures for the Saguenay River. The spectral dependence of $\mathrm{AQY} \mathrm{DOC}_{\mathrm{DOC}}$ revealed by this study, in conjunction with the solar irradiance spectrum, points to VIS and UVA being the primary drivers for photomineralization in the water column of the Saguenay River. The photomineralization rate in the Saguenay River was estimated to be $2.31 \times 10^{8} \mathrm{~mol} \mathrm{Cyr}^{-1}$, accounting for only $1 \%$ of the annual DOC input into this system.

Photomethanification occurred under both suboxic and oxic conditions and increased with decreasing $\left[\mathrm{O}_{2}\right]$, with the rate under suboxic conditions $\sim 7-8$ times that under oxic conditions. Photoproduction of $\mathrm{CH}_{4}$ under oxic conditions 
increased linearly with photochemical losses of DOC and absorbance, rendering photomineralization and photobleaching to be proxies for photomethanification. Under air saturation, $0.00057 \%$ of photochemical DOC loss in the Saguenay River surface water went to $\mathrm{CH}_{4}$, giving a photochemical $\mathrm{CH}_{4}$ production rate of $4.36 \times 10^{-6} \mathrm{~mol} \mathrm{~m}^{-2} \mathrm{yr}^{-1}$ in the Saguenay River and, by extrapolation, $(1.9-8.1) \times 10^{8}$ mol yr ${ }^{-1}$ in the global ocean. AQY $\mathrm{CH}_{4}$ changed little with photobleaching under air saturation but increased exponentially under suboxic conditions. On a depth-integrated basis, VIS prevailed over UVB in controlling $\mathrm{CH}_{4}$ photoproduction under air saturation while the opposite held true under $\mathrm{O}_{2}$-deficiency. Spiking with dissolved DMS increased $\mathrm{CH}_{4}$ photoproduction, particularly under $\mathrm{O}_{2}$-deficiency; DMS at nanomolar ambient concentrations in surface oceans is, however, unlikely a significant $\mathrm{CH}_{4}$ precursor. Although CDOM-based $\mathrm{CH}_{4}$ photoproduction is estimated to be only a marginal contributor to both the modern and Archean atmospheric $\mathrm{CH}_{4}$ budgets, its magnitude can be comparable to those of microbial $\mathrm{CH}_{4}$ oxidation in modern oxic oceans.

Future work should extend sampling coverage, quantify $\mathrm{CH}_{4}$ photoproduction from particulate organic matter, and elucidate the mechanisms of photomethanification of organic matter in natural waters, including tests on other precursors of $\mathrm{CH}_{3}$ radicals such as DMSP, dimethyl sulfoxide (DMSO), acetonitrile, methionine, methylamine and methyl ester that are naturally present in aquatic environments. For river and riverine-impacted coastal waters, particular attention should be paid to methoxy-substituted phenols in dissolved lignin, since these compounds are highly susceptible to photodegradation (Benner and Kaiser, 2011) and since the methoxy groups in certain lignin model phenols have been demonstrated to be efficient precursors of $\mathrm{CH}_{4}$ under anaerobic conditions (Weir et al., 1995). Anoxic microniches in particulate organic matter and phytoplankton cells containing elevated concentrations of methylated compounds, such as DMS, DMSP, and DMSO, may provide potential hotspots for $\mathrm{CH}_{4}$ photoproduction.

Acknowledgements. This work was supported by HX's NSERC Discovery Grant and by the National Natural Science Foundation of China (NSFC) (Grant\# 41006040). YZ was supported by a postdoctoral fellowship awarded by the Shandong International Exchange Association. Claude Belzile measured bacterial populations and DOC concentrations. Comments from two anonymous reviewers and Birgit Koehler and Lars Tranvik improved the manuscript.

Edited by: G. Herndlb

\section{References}

Aarnos, H., Ylöstalo, P., and Vähätalo, A. V.: Seasonal phototransformation of dissolved organic matter to ammonium, dis- solved inorganic carbon, and labile substrates supporting bacterial biomass across the Baltic Sea, J. Geophys. Res., 117, G01004, doi:10.1029/2010JG001633, 2012.

Alldredge, A. L. and Cohen, Y.: Can microscale chemical patches persist in the sea - microelectrode study of marine snow, fecal pellets, Science, 235, 689-691, 1987.

Anesio, A. M. and Granéli, W.: Increased photoreactiviey of DOC by acidification: Implications for the carbon cycle in humic lakes, Limnol. Oceanogr., 48, 735-744, 2003.

Arsene, C., Barnes, I., Becker, K. H., and Mocanu, R.: FT-IR product study on the photo-oxidation of dimethyl sulphide in the presence of $\mathrm{NO}_{x}$-temperature dependence, Atmos. Environ., 35 , 3769-3780, doi:10.1016/S1352-2310(01)00168-6, 2001.

Arthur, N. L. and Lee, M. S.: Reactions of methyl radicals. 1. Hydrogen abstraction from dimethyl sulfide, Aust. J. Chem., 29, 1483-1492, 1976.

Babin, M., Stramski, D., Ferrari, G. M., Claustre, H., Bricaud, A., Obolensky, G., and Hoepffner, N.: Variations in the light absorption coefficients of phytoplankton, nonalgal particles, and dissolved organic matter in coastal waters around Europe, J. Geophys. Res., 108, 3211, doi:10.1029/2001JC000882, 2003.

Bange, H. W. and Uher, G.: Photochemical production of methane in natural waters: implications for its present and past oceanic source, Chemosphere, 58, 177-183, 2005.

Bange, H. W., Bartell, U. H., Rapsomanikis, S., and Andreae, M. O.: Methane in the Baltic and North Seas and a reassessment of the marine emissions of methane, Global Biogeochem. Cy., 8, 465-480, 1994.

Bekker, A., Holland, H. D., Wang, P. L., Rumble, D., Stein, H. J., Hanna, J. L., Coetzee, L. L., and Beukes, N. J.: Dating the rise of atmospheric oxygen, Nature, 427, 117-120, 2004.

Bélanger, C.: Observation and modelling of a renewal event in the Sagueany Fjord, $\mathrm{PhD}$ thesis, Université du Québec à Rimouski, Rimouski, Québec, 2003.

Benner, R. and Kaiser, K.: Biological and photochemical transformations of amino acids and lignin phenols in riverine dissolved organic matter, Biogeochemistry, 102, 209-222, doi:10.1007/s10533-010-9435-4, 2011.

Bertilsson, S. and Tranvik, L. J.: Photochemical transformation of dissolved organic matter in lakes, Limnol. Oceanogr., 45, 753762, doi:10.4319/lo.2000.45.4.0753, 2000.

Bouillon, R. C. and Miller, W. L.: Photodegradation of dimethyl sulfide (DMS) in natural waters: Laboratory assessment of the nitrate-photolysis-induced DMS oxidation, Environ. Sci. Technol., 39, 9471-9477, doi:10.1021/es048022z, 2005.

Bourgault, D., Galbraith, P. S., and Winkler, G.: Exploratory observations of winter oceanographic conditions in the Saguenay Fjord, Atmos. Ocean, 50, 17-30, doi:10.1080/07055900.2012.659844, 2012.

Brimblecombe, P. and Shooter, D.: Photo-oxidation of dimethylsulphide in aqueous solution, Mar. Chem., 19, 343-353, 1986.

Bucciarelli, E. and Sunda, W. G.: Influence of $\mathrm{CO}_{2}$, nitrate, phosphate, and silicate limitation on intracellular dimethylsulfoniopropionate in batch cultures of the coastal diatom Thalassiosira Pseudonana, Limnol. Oceanogr., 48, 2256-2265, 2003.

Buiteveld, H., Hakvoort, J. M. H., and Donze, M.: The optical properties of pure water, in:SPIE Proceedings on Ocean Optics XII, edited by: Jaffe, J. S., 2258, 174-183, 1994. 
Cicerone, R. J. and Oremland, R. S.: Biogeochemical aspects of atmospheric methane, Global Biogeochem. Cy., 2, 299-327, doi:10.1029/GB002i004p00299, 1988.

CIS (Canadian Ice Service): Sea Ice Climatic Atlas: East Coast of Canada, 1971-2000, Canadian Government Publishing, Ottawa, 2001.

Cockell, C. S.: Biological e?ects of high ultraviolet radiation on early Earth - A theoretical evaluation, J. Theor. Biol., 193, 717729, 1998.

Cory, R. M., Ward, C. P., Crump, B. C., and King, G. W.: Sunlight controls water column processing of carbon in arctic fresh waters, Science, 345, 925-928, doi:10.1126/science.1253119, 2014.

Damm, E., Kiene, R. P., Schwarz, J., Falck, E., and Dieckmann, G.: Methane cycling in Arctic shelf water and its relationship with phytoplankton biomass and DMSP, Mar. Chem., 109, 4559, doi:10.1016/j.marchem.2007.12.003, 2008.

Damm, E., Helmke, E., Thoms, S., Schauer, U., Nöthig, E., Bakker, K., and Kiene, R. P.: Methane production in aerobic oligotrophic surface water in the central Arctic Ocean, Biogeosciences, 7, 1099-1108, doi:10.5194/bg-7-1099-2010, 2010.

Damm, E., Thoms, S., Beszczynska-Möller, A., Nöthig, E. M., and Kattner, G.: Methane excess production in oxygen-rich polar water and a model of cellular conditions for this paradox, Polar Science, 9, 327-334, doi:10.1016/j.polar.2015.05.001, 2015.

Del, Vecchio, R. and Blough, N. V.: Photobleaching of chromophoric dissolved organic matter in natural waters: Kinetics and modelling, Mar. Chem., 78, 231-253, 2002.

Drainville, G.: Le fjord du Saguenay: I. Contribution à l'océanographie, Nat. Can., 95, 809-855, 1968.

Esplugas, S., Giménez, J., Contreras, S., Pascual, E., and Rodríguez, M.: Comparison of different advanced oxidation processes for phenol degradation, Water Res., 36, 1034-1042, 2002.

Fichot, C. G. and Benner, R.: The fate of terrigenous dissolved organic carbon in a river-influenced ocean margin, Global Biogeochem. Cy., 28, 1-19, doi:10.1002/2013GB004670, 2014.

Florez-Leivaa, L., Dammb, E., and Farías, L.: Methane production induced by dimethylsulfide in surface water of an upwelling ecosystem, Prog. Oceanogr., 112-113, 38-48, doi:10.1016/j.pocean.2013.03.005, 2013.

Frimmel, F. H.: Photochemical aspects related to humic substances, Environ. Int., 20, 373-385, 1994.

Gao, H. and Zepp, R. G.: Factors influencing photoreactions of dissolved organic matter in a coastal river of the southeastern United States, Environ. Sci. Technol., 32, 2940-2946, 1998.

Gueymard, C.: SMARTS2, a simple model of the atmospheric radiative transfer of sunshine: algorithms and performance assessment, Professional Paper FSEC-PF-270-95, Florida Solar Energy Center, Cocoa, Florida, USA, 1995.

Gueymard, C.: Parameterized transmittance model for direct beam and circumsolar spectral irradiance, Sol. Energy, 71, 325-346, 2001.

Helms, J. R., Stubbins, A., Ritchie, J. D., Minor E. C., Kieber, D. J., and Mopper, K.: Absorption spectral slopes and slope ratios as indicators of molecular weight, source, and photobleaching of chormophoric dissolved organic matter, Limnol. Oceanogr., 53, 955-969, 2008.

Hong, J., Xie, H., Guo, L. D., and Song, G. S.: Carbon monoxide photoproduction: implications for photoreactivity of Arctic permafrost-derived soil dissolved organic matter, Environ. Sci. Technol, 48, 9113-9121, 2014.

Hu, C., Muller-Karger, F. E., and Zepp, R. G.: Absorbance, absorption coefficient, and apparent quantum yield: A comment on common ambiguity in the use of these optical concepts, Limnol. Oceanogr., 47, 1261-1267, 2002.

IPCC: Climate change 2013: the physical science basis, in Contribution of Working Group I to the Fifth Assessment Report of the Intergovernmental Panel on Climate Change, Cambridge University Press, Cambridge, UK, 2013.

Johannessen, S. C. and Miller, W. L.: Quantum yield for the photochemical production of dissolved inorganic carbon in seawater, Mar. Chem., 76, 271-283, 2001.

Karl, D. M., Beversdorf, L., Bjorkman, K. M., Church, M. J., Martinez, A., and DeLong, E. F.: Aerobic production of methane in the sea, Nat. Geosci., 1, 473-478, 2008.

Keller, M. D., Bellows, W. K., and Guillard, R. R. L.: Dimethylsulfide production in marine phytoplankton, in: Biogenic Sulfur in the Environment, edited by: Saltzman, E. S. and Cooper, W. J., American Chemical Society, Washington, DC, 167-182, 1989.

Kieber, D. J., McDaniel, J., and Mopper, K.: Photochemical source of biological substrates in sea water: implications for carbon cycling, Nature, 341, 637-639, doi:10.1038/341637a0, 1989.

Liss, P. S., Marandino, C. A., Dahl, E. E., Helmig, D., Hintsa, E. J., Hughes, C., Johnson, M. T., Moore, R. M., Plane, J. M. C., Quack, B., Singh, H. B., Stefels, J., von Glasow, R., and Williams, J.: Short-lived trace gases in the surface ocean and the atmosphere, in: Ocean-atmosphere interactions of gases and particles, edited by: Liss, P. S. and Johnson, M. T., Springer Open, Berlin, Heidelberg, 1-54, 2014.

Lou, T. and Xie, H.: Photochemical alteration of molecular weight of dissolved organic matter, Chemosphere, 65, 2333-2342, 2006.

McDiarmid, R.: Assignment of rydberg and valence transitions in the electronic spectrum of dimethylsulphide, J. Chem. Phys., 61, 274-281, 1974.

Metcalf, W. W., Griffin, B. M., Cicchillo, R. M., Gao, J., Janga, S. C., Cooke, H. A., Circello, B. T., Evans, B. S., MartensHabbena, W., Stahl, D. A., and van der Donk, W. A.: Synthesis of methylphosphonic acid by marine microbes: a source for methane in the aerobic ocean, Science, 337, 11104-11107, 2012.

Miles, C. J. and Brezonik, P. L.: Oxygen consumption in humic-colored waters by a photochemical ferrous-ferric catalytic cycle, Environ. Sci. Technol., 15, 1089-1095, doi:10.1021/es00091a010, 1981.

Miller, W. L. and Zepp, R. G.: Photochemical production of dissolved inorganic carbon from terrestrial organic matter: significance to the oceanic organic carbon cycle, Geophys. Res. Lett., 22, 417-420, 1995.

Miller, W. L., Moran, M. A., Sheldon, W. M., Zepp, R. G., and Opsahl, S.: Determination of apparent quantum yield spectra for the formation of biologically labile photoproducts, Limnol. Oceanogr., 47, 343-352, 2002.

Molot, L. A., Hudson, J. J., Dillon, P. J., and Miller, S. A.: Effect of $\mathrm{pH}$ on photo-oxidation of dissolved organic carbon by hydroxyl radicals in a coloured softwater stream, Aquat. Sci., 67, 189-195, 2005.

Mopper, K. and Kieber, D. J.: Photochemistry and the cycling of carbon, sulfur, nitrogen and phosphorus, in: Biogeochemistry of marine dissolved organic matter, edited by: Hansell, D. A. and 
Carlson, C. A., Academic Press, San Diego, USA, 456-508, 2002.

Mopper, K. and Zhou, X. L.: Hydroxyl radical photoproduction in the sea and its potential impact on marine processes, Science, 250, 661-664, doi:10.1126/science.250.4981.661, 1990.

Mopper, K., Kieber, D. J., and Stubbins, A.: Marine Photochemistry of Organic Matter: Processes and Impacts, in: Biogeochemistry of marine dissolved organic matter, edited by: Hansell, D. A. and Carlson, C. A., second Edn., Academic Press, San Diego, USA, 389-450, 2015.

Moran, M. A. and Zepp, R. G.: Role of photoreactions in the formation of biologically labile compounds from dissolved organic matter, Limnol. Oceanogr., 42, 1307-1316, 1997.

Neta, P., Grodkowski, J., and Ross A. B.: Rate constants for reactions of aliphatic carbon-centered radicals in aqueous solution, J. Phys. Chem. Ref. Data, 25, 709-718, doi:10.1063/1.555978, 1996.

Obernosterer, I. and Benner, R.: Competition between biological and photochemical processes in the mineralization of dissolved organic carbon, Limnol. Oceanogr., 49, 117-124, doi:10.4319/lo.2004.49.1.0117, 2004

Osburn, C. L., Zagarese, H. E., Morris, D. P., Morris, Hargreaves, B. R., and Cravero, W. E.: Calculation of spectral weighting functions for the solar photobleaching of chromophoric dissolved organic matter in temperate lakes, Limnol. Oceanogr., 46, 14551467, 2001.

Osburn, C. L., Retamal, L., and Vincent, W. F.: Photoreactivity of chromophoric dissolved organic matter transported by the Mackenzie River to the Beaufort Sea, Mar. Chem., 115, 10-20, doi:10.1016/j.marchem.2009.05.003, 2009.

Pope, R. M. and Fry, E. S.: Absorption spectrum (380-700 nm) of pure water, II, Integrating cavity measurements, Appl. Optics, 36, 8710-8723, 1997.

Raymond, P. A. and Spencer, R. G. M.: Riverine DOM, in: Biogeochemistry of marine dissolved organic matter, edited by: Hansell, D. A. and Carlson, C. A., second Edn., Academic Press, San Diego, USA, 509-533, 2015.

Reader, H. E. and Miller, W. L.: Variability of carbon monoxide and carbon dioxide apparent quantum yield spectra in three coastal estuaries of the South Atlantic Bight, Biogeosciences, 9, 42794294, doi:10.5194/bg-9-4279-2012, 2012.

Reeburgh, W. S.: Oceanic methane biogeochemistry, Chem. Rev., 107, 486-513, 2007.

Roy, R., Campbell, P. G. C., Prémont, S., and Labrie, J.: Geochemistry and toxicity of aluminum in the Saguenay River, Québec, Canda, in relation to discharges from an alumiunum smelter, Environ. Toxicol. Chem., 19, 2457-2466, 2000.

Schafer, C. T., Smith, J. N., and Côté, R.: The Saguenay Fjord: A major tributary to the St. Lawrence Estuary, in: Oceanography of a large-scale estuarine system the St. Lawrence, edited by: ElSabh, M. I. and Silverberg, N., Vol. 39, Springer-Verlag, New York, USA, 378-420, 1990.

Schmale, O., Haeckel, M., and McGinnis, D. F.: Response of the Black Sea methane budget to massive short-term submarine inputs of methane, Biogeosciences, 8, 911-918, doi:10.5194/bg-8911-2011, 2011.

Song, G., Xie, H., Bélanger, S., Leymarie, E., and Babin, M.: Spectrally resolved efficiencies of carbon monoxide $(\mathrm{CO})$ photoproduction in the western Canadian Arctic: particles versus solutes,
Biogeosciences, 10, 3731-3748, doi:10.5194/bg-10-3731-2013, 2013.

Stubbins, A., Uher, G., Law, C. S., Mopper, K., Robinson, C., and Upstill-Goddard, R. C.: Open-ocean carbon monoxide photoproduction, Deep-Sea Res. Pt. II, 53, 1695-1705, 2006.

Sunda, W. G., Hardison, R., Kiene, R. P., Bucciarelli, E., and Harada, H.: The effect of nitrogen limitation on cellular DMSP and DMS release in marine phytoplankton: climate feedback implications, Aquat. Sci., 69, 341-351, 2007.

Tilbrook, B. D. and Karl, D. M.: Methane sources, distributions, and sinks from California coastal waters to the oligotrophic North Pacific gyre, Mar. Chem., 49, 51-64, 1995.

Tremblay, L. and Gagné, J. P.: Organic matter distribution and reactivity in the waters of a large estuarine system, Mar. Chem., 116, $1-12,2009$.

True, M. B. and Zafiriou, O. C.: Reaction of $\mathrm{OH}$ radical with seawater - formation of $\mathrm{Br}_{2}^{-}$and subsequent reaction with carbonate, in: Abstracts of papers of the American Chemical Society, Vol. 189, No. Apr, 3-GEOC. 1155 16th St., NW, Washington, DC, 20036: American Chemical Society, 1985.

Vähätalo, A. V. and Wetzel, R. G.: Photochemical and microbial decomposition of chromophoric dissolved organic matter during long (months-years) exposures, Mar. Chem., 89, 313-326, doi:10.1016/j.marchem.2004.03.010, 2004.

Vähätalo, A. V., Salkinoja-Salonen, M., Taalas, P., and Salonen, K.: Spectrum of the quantum yield for photochemical mineralization of dissolved organic carbon in a humic lake, Limnol. Oceanogr., 45, 664-676, 2000.

Weller, D. I., Law, C. S., Marriner, A., Nodder, S. D., Chang, F. H., Stephens, J. A., Wilhelm, S. W., Boyd, P. W., and Sutton, P. J. H.: Temporal variation of dissolved methane in a subtropical mesoscale eddy during a phytoplankton bloom in the southwest Pacific Ocean, Prog. Oceanogr., 116, 193-206, 2013.

Weir, N. A., Arct, J., and Ceccarellik, A.: Photodegradation of lignin model compounds: part 2 - substituted stilbenes, Polym. Degrad. Stabil., 47, 289-297, 1995.

Williams, M. B., Campuzano-Jost, P., Hynes, A. J., and Pounds A. J.: Experimental and theoretical studies of the reaction of the $\mathrm{OH}$ radical with alkyl sulfides: 3 . kinetics and mechanism of the $\mathrm{OH}$ initiated oxidation of dimethyl, dipropyl, and dibutyl sulfides: Reactivity trends in the alkyl sulfides and development of a predictive expression for the reaction of $\mathrm{OH}$ with DMS, J. Phys. Chem. A, 113, 6697-6709, 2009.

Xie, H., Andrews, S. S., Martin, W. R., Miller, J., Ziolkowski, L., Taylor, C. D., and Zafiriou, O. C.: Validated methods for sampling and headspace analysis of carbon monoxide in seawater, Mar. Chem., 77, 93-108, 2002.

Xie, H., Zafiriou, O. C., Cai, W. J., Zepp, R. G., and Wang, Y.: Photooxidation and its effects on the carboxyl content of dissolved organic matter in two coastal rivers in the southeastern United States, Environ. Sci. Technol., 38, 4113-4119, 2004.

Xie, H., Zhang, Y., Lemarchand, K., and Poulin, P.: Microbial carbon monoxide uptake in the St. Lawrence estuarine system, Mar. Ecol.-Prog. Ser., 389, 17-29, doi:10.3354/meps08175, 2009.

Xie, H., Aubry, C., Bélanger, S., and Song, G.: The dynamics of absorption coefficients of CDOM and particles in the St Lawrence estuarine system: Biogeochemical and physical implications, Mar. Chem., 128-129, 44-56, 2012. 
Zafiriou, O. C.: Sunburnt organic matter: Biogeochemistry of lightaltered substrates, Limnol. Oceanogr. Bull., 11, 69-86, 2002.

Zafiriou, O. C. and True, M. B.: Nitrate photolysis in seawater by sunlight, Mar. Chem., 8, 33-42, doi:10.1016/03044203(79)90030-6, 1979.
Zindler, C., Bracher, A., Marandino, C. A., Taylor, B., Torrecilla, E., Kock, A., and Bange, H. W.: Sulphur compounds, methane, and phytoplankton: interactions along a north-south transit in the western Pacific Ocean, Biogeosciences, 10, 3297-3311, doi:10.5194/bg-10-3297-2013, 2013. 